を求めて比較した． $\mathrm{Fe}^{3+}$ 濃度としては，処理液に浸せ きする前の武料中の $\mathrm{Fe}^{3+}$ 量を含水量で割った值を使用 した. したがって劣化の処理液中には $\mathrm{NaCl}$ が存在す るため，当然 $\mathrm{Na}^{+}$と $\mathrm{Fe}^{3+}$ との間住交換反応が行なわ

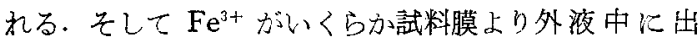
るはずであり，劣化有効な $\mathrm{Fe}^{3+}$ 濃度は低下するが $\mathrm{Fe}^{3+}$ の交換吸着性が， $\mathrm{Na}^{+}$飞比して大新いことから， 補正は行なわなかった。

乾燥樹脂量の変化は, 劣化化よる樹脂の溶出を示し, 亿オン交換基の数の変化は，䄈脂の溶出飞伴う損失とイ オン交換基自身の少化による損失とを含む。乙かし，イ オン交換基の数の減少は, 乾燥樹脂量江関する劣化度と よく似た傾向を示すことから，樹脂の溶出による損失が 支配的であると思われる. 含水量の変化心, 樹脂構造の ゆるみの度合を示すものと考光られ，固定イオン濃度 は、樹脂構造のゆるみとイオン交換基の減少文っって。 大きく低下する，そして，輸率飞関する少化は，その度 合が大きすぎるために，輸率の変化から各試料の比較を することはできなかった，比電導度は含水量任ど大きな 変化を示さなかったが，樹脂構造のゆるるとよる脱抵抗 の減少とイオン交換基の減少に上る膜抵抗の增大と， 2 つの相反する要因の影響によるものと思われる.膜の安 定性, すなわち，乏の敖脂構造の安定性を比較するため には，樹脂構造の恋化を直接的に示すと考兄られる乾燥 樹脂量，イオン交換基数と含水量を尺度として使用する のが適当と思われる、次の專がらが明らかとなる（I） $\mathrm{Fe}^{3+}$ 濃度の増大とともに劣化の度合は大到くなる. (II) P膜では,フェノール/メタフェノールスルホン酸ソーダ （モル比）の3.0のものが2.5のものより明らか忙安定 である. (III) $\mathrm{B}$ 膜では, ビスフェノール A/メタフェノ 一ルスルホン酸ソーダ(モル比)が，1.25 と 1.50 の場合 では，明らが 1.50 の場合がより安定であるとい方る。 (IV) $\mathrm{B}$ 膜は $\mathrm{P}$ 膜上り安定である.重合型イオン交換体を $\mathrm{H}_{2} \mathrm{O}_{2}$ Kより劣化せしめる際に，鉄を存在せしめると劣
化が促進され゚〜11，その機構はラジカル機構であると報

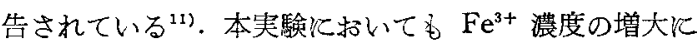
より，劣化の度合は大きくなっている.ラジカル機構に より樹脂構造中の弱点が攻慗されて㪇脂の溶出が起るも のと思われる，そして，P膜がB膜上り，そういった弱 点を多く有寸るものと考完られるが棌細は不明である。

$\mathrm{B}$ 膜, $\mathrm{P}$ 膜ともに，それぞれビスフェノールA含量，フ エノール合量が增大すると, 安定性が増大しているが, 窝強面積泪当すると考光られる含水量が減少している ことによるものと思われる．以上の結果は，B膜がP膜 そ比してアルカリ触媒による熱硬化特の着色の度合が少 なかったことと前述の中村の報告とをあわせて考觉た場 合, 当然の結罙であるう.

\section{4. 総括}

メタフェノールスルホン酸ソーダ, ビスフェノール A 招よびホルムアルデヒドを縮重合せしめて陽イオン交換 膜を製造し，膜特性がメタフェノールスルホン酸ソー ダ,フェノール执よびホルムアルデヒドより成る陽イオ ン交換膜とよく似ていることを認めた. $\mathrm{Fe}^{3+}-\mathrm{H}_{2} \mathrm{O}_{2}$ 系に よる少化詰験の結果，前者がより安定であること，括よ び同一系の膜では，含水量の小さいものほど安定である ことを認めた。

(昭 35-9-15 受理)

文 献

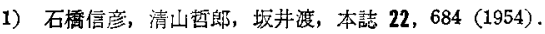

2）中沢治男，尾上康治，水谷幸雄，工化 61，789 (1958).

3）尾上康治, 水谷幸雄, 山根礼一, 本就 27，482 (1959).

4) T.R.E. Kressman, J.A. Kitchener, J. Chem. Soc. 1949, 1190.

5) 中村儀郎, 工化 59, 453 (1956).

6) 中村儀郎, 化学々工丵 10,224 (1957).

7) 中村儀郎, 工化 61, 480 (1958).

8) 中村儀郎, 工化 60, 785 (1957).

9) J.J. Collins, E.R. Litterio, R.L. Markus, Ind. Eng.Chem. 49, 1843 (1957).

10) W. Wood, J. Phys. Chem. 61, 832 (1957).

11) H.J. Hookway, B. Selton, J. Phys. Chem. 62, 493 (1958).

\title{
メタフェノールスルホン酸系陽イオン交換膜の選択透過性の改良についで*
}

\section{Improvement of Cation Exchange Membranes for the Permselectivity}

尾上康治**, 水谷幸雄**, 手島亘**, 山根礼一**, 秋山澄雄** Yasuharu Onoue, Yukio Mizutani, Wataru Teshima, Reiichi Yamane, Sumio Akiy ama

\section{1. 緒言}

イオン交掺膜を使用して海水の電解濃縮を有利に行な

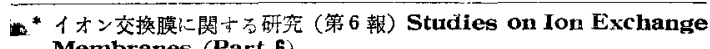
Membranes (Part 6)

** 徳山曹達栋式会社研究部（德山市大学德山 8355）
ろためには

（イ）良好な霞力原単位を得ること，(口）得られる かん水中の $\mathrm{Ca}^{2+}, \mathrm{Mg}^{2+}$ の少小いと，(八）操業中 の $\mathrm{CaCO}_{3}, \mathrm{CaSO}_{4}$ の析出を括さ充, その沈殿析出沉 伴う障害を澼けるととが必要である。そのためには， 
使用するイオン交換膜に

（1）高選択透過性を有すること，（2）高電導性を 有すること，(3) 陽イオン交換膜では， $\mathrm{Ca}^{2+}, \mathrm{Mg}^{2+}$ を，陰イオン交換膜では $\mathrm{SO}_{4}{ }^{2-}, \mathrm{CO}_{3}{ }^{2-}$ を透過せしめ 泫ととと，(4) 耐久性を有すること が要求され る.しかし、これらの条件をすべて満足させるような膜 の製造は容易ではない。

フェノールスルホン酸ーフェノールーホルムアルデヒド 系膜に括いては，すで報告されているようにフェノー ル含量の増大とともに輸率は上昇し, 極大值に達した後 再び低下するが，此電導度はフェノール含量增大ととも に小さくなる、したがって実用に際しては，翰率と比雷

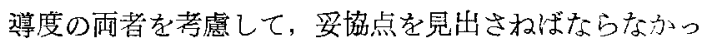
$た^{1)}$. 一方,フェノール含量の増大によって, $\mathrm{Ca}^{2+}, \mathrm{Mg}^{2+}$ が透過しがたくなることが翀められているが，反面比電

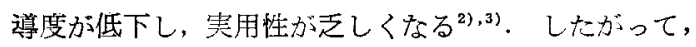
かかる膜を実用に供する場合には, 膜を薄くすることに 上り，実效抵抗を淢少させ称ばならないが，機械的強度 が問題になってくるのでフェノール含量の大きい膜は使 用できないまたつェノール含量の小さい牀イオン交換 膜では, 実效抵抗の小さいものが得られるが, 電解濃縮 の際, か九水中の $\mathrm{Ca}^{2+}, \mathrm{Mg}^{2+}$ の濃縮比は $\mathrm{Na}^{+}$の濃縮 比上りも大きく, 得られるかん水怟品位のるのとな り, $\mathrm{CaCO}_{3}, \mathrm{CaSO}_{4}$ の析出原因ともなる. 以上述べた ように, ただ単にフェノール含量を変光ることによっ て，より実用に適した膜を得ることは困難であった。

かかる難点を改良する目的で，良好な比電導度和よび 輸率を示すようなフェノール含量の膜の上飞, $\mathrm{Ca}^{2+}$, $\mathrm{Mg}^{2+}$ を透過させがたく，比較的フェノール含量の大き い陽イオン交換樹脂を，薄膜状に固着させることによ り，従来実用に供されてきた膜に比して，より突用性の 高い膜が得られるようになった.このよろにして得られ た膜を“選択性膜”之呼称する。この選択性膜につい て, 諸性質の測定扔よび小規模な海水の電解濃縮実験を 行ない，実用性の高いことを認めた。

\section{2. 実験}

\section{1 試料膜}

メタフェノールスルホン酸ソーダ (m.p.s.s.)-フェ， ールーホルムアルデとド膜を使用した.

衰 1 原料配合比 (モル)

\begin{tabular}{|c|c|c|c|c|}
\hline 原 料 No. & No. 1 & No. 2 & No. 3 & No. 4 \\
\hline$\frac{フ_{ \pm} \prime-ル}{\text { m.p.s.s. }}$ & 2.0 & 3.0 & 4.0 & 5.0 \\
\hline$\frac{\text { ホルムアルデヒト }}{\text { フォスール+m.p.s.s. }}$ & 2.7 & 2.7 & 2.7 & 2.7 \\
\hline
\end{tabular}

表】に示した No. 1 の配合比の原料飞適量の力七イ ソーダを触媒として加克た後, 温浴上で加熱し，得られ
る粘稠な初期重合物をガラス布を基材として膜状㳊成型

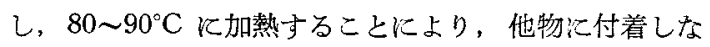
い程度に樹脂化さしめた. 次いでその上に，それぞれ No. 2 , No. 3 括上び No. 4 者同様汇処理乙て得方九 る粘䅕な初期笪合物を均一に薄く㳂布し, $80 \sim 90^{\circ} \mathrm{C}$ K 暫時加熱後, $140 \sim 150^{\circ} \mathrm{C} 飞 8 \mathrm{~h}$ 加熱して樹脂化さむた。

得られた膜は，以上 No. (A-B) として表示する.た だし，Aは基体部分の，また $\mathrm{B}$ は塗布した選択性部分の フェノール/m.p.s.s.(モル比)である. 塗布した選执性部 分の厚さは, 全体の5〜8\%占める6のと思われる.

なお，比較のために，同一条件下で選択化処理を行な わない算一組成の膜を, フェノール含量を薪化させて作 ot.

\section{$2 \cdot 2$ 膜性質の測定}

含水量, 交換容量, 固定イオン濃度, 比臂導度括よび 輸率の測定は睹報の手法 ${ }^{2}$ 亿捝った。

\section{3 海水の電解濃樎実験}

簡単なロ過を行なった海水を使用し，小型サンドウィ ッチ型の電解濃縮りウ安使用した。陰イオン交換膜は柕 塩基性膜を使用した，香它陽イオン交換膜は選択化处理 を施した面を海水側淌けて使用した。

\section{3. 結果亡考察}

\section{1 膜の電気化学的性質}

測定結果を表 2 に示した。

\section{表 2 膜の電気化学的性質}

\begin{tabular}{|c|c|c|c|c|}
\hline & No. & No. $(2-3)$ & No. $(2-4)$ & No. $(2-5)$ \\
\hline & 量 $\left(\frac{\mathrm{g} \cdot \mathrm{H}_{2} \mathrm{O}}{\mathrm{g} \cdot \mathrm{Na} \text { 型乾煴樹脂 }}\right)$ & 0.42 & 0.42 & 0.39 \\
\hline 交控 & 量 $\left(\frac{\Sigma y \text { 当量 }}{\text { g.Na型乾燥樹脂 }}\right)$ & 1.58 & 1.54 & 1.42 \\
\hline & 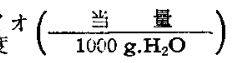 & 3.76 & 3.67 & 3.74 \\
\hline 比電 & 度 $\mathrm{Mg}$ 型* $\left(\Omega^{-1} \mathrm{~cm}^{-1}\right)$ & $0.40 \times 10^{-3}$ & $0.36 \times 10^{-3}$ & $0.11 \times 10^{-3}$ \\
\hline 圠管 & 度 $\mathrm{Na}$ 刑" $\left(\Omega^{-1} \mathrm{~cm}^{-1}\right)$ & $2.5 \times 10^{-3}$ & $2.2 \times 10^{-3}$ & $1.2 \times 10^{-3}$ \\
\hline 輸 & 率** & 85.0 & 85.7 & 87.2 \\
\hline 厚 & $(\mathrm{mm})$ & 0.22 & 0.21 & 0.22 \\
\hline
\end{tabular}

* $0.5 \mathrm{~N} \mathrm{NaCl}$ なたは $\mathrm{MgCl}_{2}$ 中ての $25^{\circ} \mathrm{C}$ における值

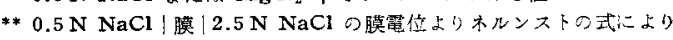
算出した值. 测定温度 $25^{\circ} \mathrm{C}$

フェノール含量の大きい選択処理部分の, 樹脂全体に 刘する割合が小さいため，合水量，交換容量扰よび固定 イオン濃度にはおまり大きな変化は認められないか，選 択処理部分のフェノール含量堌大とともに，含水量，交 換容量执よび比電導度は減少の傾向を示し，輸率は上昇 の傾向を示した．表 3 亿比咬のために，フェノール含量 を変化させた単一組成膜の比電導度と輸率を示した。 たこれらを図1にプロットして比較した。

図1から，翰率と比電導度の関係に拾いて，選択览膜 は上り高い実用性を示していることが明らかで市る。こ れは実効抵抗を大幅に変化せしめない㕵度に, 薄膜状に 
表 3 輸率と比電導度

\begin{tabular}{|c|c|c|c|c|c|c|c|}
\hline 嗯 No. & No. 1 & No. 2 & No. 3 & No. 4 & No. 5 & No. 6 & No. 7 \\
\hline$\frac{J_{x} ノ ー N}{\text { m.p.s.s. }}$ & 2.0 & 2.5 & 3.0 & 3.5 & 4.0 & 4.5 & 5.0 \\
\hline 比電導度 $\mathbf{M g}$ 型 & $1.3 \times 10^{-3}$ & $0.73 \times 10^{-3}$ & $0.27 \times 10^{-3}$ & $0.20 \times 10^{-3}$ & $0.087 \times 10^{-3}$ & $0.018 \times 10^{-3}$ & $0.011 \times 10^{-3}$ \\
\hline 此電尊度 $\mathrm{Na}$ 型 & $3.7 \times 10^{-3}$ & $2.7 \times 10^{-3}$ & $1.5 \times 10^{-3}$ & $1.1 \times 10^{-3}$ & $0.54 \times 10^{-3}$ & $0.18 \times 10^{-3}$ & $0.11 \times 10^{-3}$ \\
\hline 牟 & 76.0 & 80.5 & 85.6 & 86.0 & 84.9 & 84.5 & 83.5 \\
\hline
\end{tabular}

付けるものであった。

\section{2 海水の電解灌鞭実 験}

表 4 に濃縮力九水の組成 を示した.

またフェノール含量を変

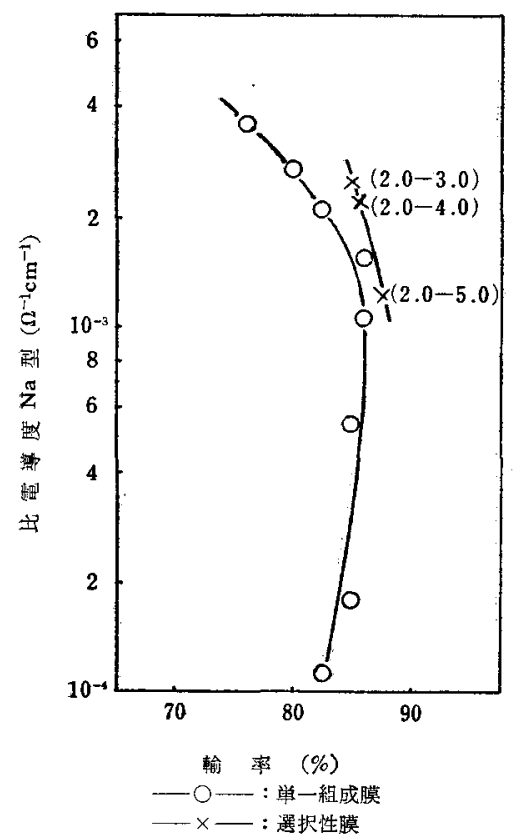

図】輸率と比電導度
固着せしめた 選択処理部分 が, 輸率を増 大させている ことに基くる のである。

膜责透過与 るイオンの動 きやすさは比 電導度と密接 な関係があ る、そこで表 2 括よび表 3 の $\mathrm{Mg}$ 型と $\mathrm{Na}$ 型の比電 導度比を図 2 に示した・た だし選択性膜 の場合屾選択 性部分のフェ ノ $-ル / \mathrm{m} \cdot \mathrm{p}$.

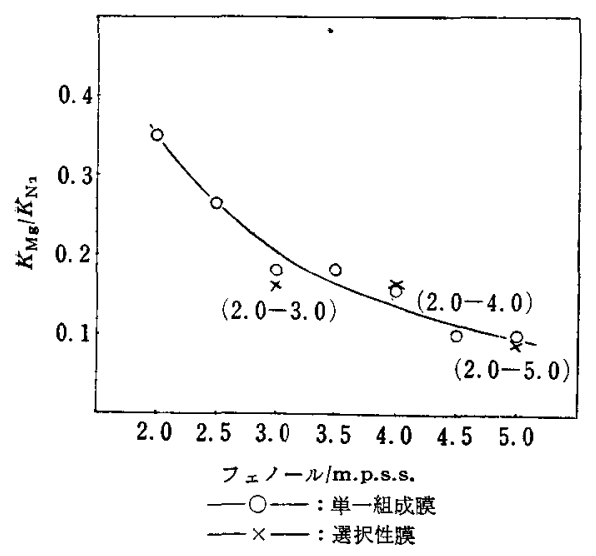

図2 組成による比電導度比の变化

s.s. (モル比) についてプロットした.

図 2 から，選扒性膜の比電導度比が，選択性部分の比 電導度比によって支配されていることが明らかである。

したがって，選択性膜は輸率と比電導度の関係に括い て, 従来の単一組成の膜に比して，より実用的であるだ けでなく， $\mathrm{Ca}^{2+}, \mathrm{Mg}^{2+}$ を透過させがたい性質を有する ことが考光られ，海水の電解濃縮実験の結果もこれを裹
化させた膜を使用した場合の， $\mathrm{Ca}^{2+}, \mathrm{Mg}^{2+}$ の濃縮比を 表 5 に示した。

表 4 濃縮か九水の組成 (N)

\begin{tabular}{|c|c|c|c|}
\hline 膛 No. & No. $(2-3)$ & No. $(2-4)$ & No. $(2-5)$ \\
\hline$c_{\mathrm{Cl}}$ & 3.423 & 3.101 & 2.800 \\
\hline$c_{\mathrm{SO}}$ & 0.100 & 0.087 & 0.217 \\
\hline$c_{\mathrm{H}}$ & - & - & 0.050 \\
\hline$c_{\mathrm{K}}$ & 0.114 & 0.111 & 0.119 \\
\hline$c_{\mathrm{Ca}}$ & 0.123 & 0.091 & 0.057 \\
\hline$C_{\mathrm{Mg}}$ & 0.559 & 0.444 & 0.243 \\
\hline$C_{\mathrm{Na}}$ & 2.73 & 2.54 & 2.60 \\
\hline$P_{\mathrm{K}}$ & 1.54 & 1.61 & 1.70 \\
\hline$P_{\mathrm{Ca}}$ & 0.99 & 0.81 & 0.55 \\
\hline$P_{\mathrm{Mg}}$ & 0.88 & 0.75 & 0.40 \\
\hline
\end{tabular}

海水温度 $24.5^{\circ} \mathrm{C}$, 電流密度 $0.8 \mathrm{~A} / \mathrm{cm}^{2}$.

$P_{\mathrm{M}}=\frac{C_{\mathrm{CM}}}{C_{\mathrm{SM}}} \div \frac{C_{\mathrm{CNa}}}{C_{\mathrm{SNa}}} \quad$ たたしCょょび 在表わ吉。

表 5

\begin{tabular}{c|c|c|c|c}
\hline 膜 No. & No. 2 & No. 3 & No. 4 & No. 5* \\
\hline$P_{\mathrm{Ca}}$ & 1.7 & 1.6 & 1.3 & 0.6 \\
$P_{\mathrm{Mg}}$ & 0.9 & 0.8 & 0.8 & 0.2 \\
\hline
\end{tabular}

，湦縮液流酸性

No. (2-3), No. (2-4) は，同じ比電導度值を有する 单一組成膜と比較した場合， $P_{\mathrm{Ca}}, P_{\mathrm{Mg}}$ は小さい值を示 している. 特に $P_{\mathrm{Ca}}$ の減少が目立つているが，これは 選択性部分のフェノール含量が大きいので，その密な樹 脂構造によるフルイ効果によるものと䒮党られる. また 選択性部分のフェノール合量が大きくなると，たとえ ば, No.（2-5）のように濃縮液の酸性化が起るようにな る.この酸性化の問題招よび電解濃縮時の $\mathrm{Ca}^{2+}, \mathrm{Mg}^{2+}$ の挙動に関しては, 稿を改めて報告する.

\section{4. 総括}

（1）メタフェノールスルホン酸系陽イオン交換膜に つて,比較的フェノール含量の小さい樹脂を基体とし, その上に比較的フェノール含量の大きい樹脂を薄膜状に 固着させることにより, 從来の単一組成膜に比して,よ り実用的な膜が得られた。

（2）海水の電解濃縮に際し， $\mathrm{Ca}^{2+}, \mathrm{Mg}^{2+}$ が比較的 濃縮されがたいことを認めた。（昭 35-9-15 受理）

\section{文 献}

1）中沢治男，尾上康治，水谷幸雄，工化 61，789（1958）。

2）尾上唐治，水谷幸雄，山根礼一，本誌 27，482 (1959)。

3) 尾上康治, 水谷幸雄, 山根礼一, 高椅芳晴, 本誌 29, 187 (1961). 